\title{
Anayde Corrêa de Carvalho: life and contributions to Bahia's Nursing School
}

\author{
Anayde Corrêa de Carvalho: vida e contributos para a Escola de Enfermagem da Bahia \\ Anayde Corrêa de Carvalho: vida y contribuciones a la Escuela de Enfermería de Bahía
}

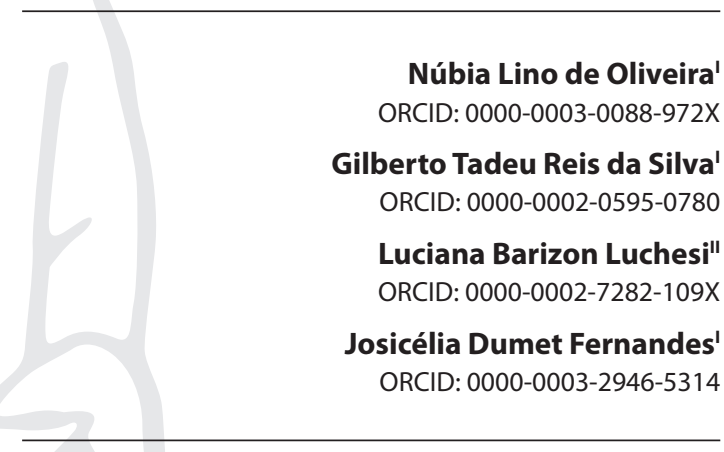

'Universidade Federal da Bahia. Salvador, Bahia, Brazil. "Universidade de São Paulo. Ribeirão Preto, São Paulo, Brazil.

How to cite this article: Oliveira NL, Silva GTR, Luchesi LB, Fernandes JD. Anayde Corrêa de Carvalho: life and contributions to Bahia's Nursing School. Rev Bras Enferm. 2021;74(1):e20200361. doi: http://dx.doi.org/10.1590/0034-7167-2020-0361

Corresponding author: Núbia Lino de Oliveira E-mail: nubialinodeoliveira@gmail.com

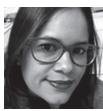

EDITOR IN CHIEF: Dulce Barbosa ASSOCIATE EDITOR: Antonio José de Almeida Filho

\section{ABSTRACT}

Objectives: to analyze the life and career of Anayde Corrêa de Carvalho and her contributions to nursing in Bahia. Methods: oral history of her life and documentary research, with thematic content analysis. Results: three categories were found: Personal Trajectory of Anayde Corrêa de Carvalho; The School of Nursing of Bahia; and School of Nursing of the University of São Paulo and Brazilian Nursing Association. Final Considerations: this study made it possible to analyze the life of an ethical and committed nurse, who dedicated herself to nursing education and research and contributed significantly to the construction of the image and development of nursing as a profession in Bahia.

Descriptors: Nursing; History of Nursing; Biography; History, 20th Century; Qualitative Research.

\section{RESUMO}

Objetivos: analisar a trajetória de vida de Anayde Corrêa de Carvalho e seus contributos para a enfermagem baiana. Métodos: história oral de vida e pesquisa documental, com análise de conteúdo temática. Resultados: evidenciaram-se três categorias: Trajetória Pessoal de Anayde Corrêa de Carvalho; A Escola de Enfermagem da Bahia; e Escola de Enfermagem da Universidade de São Paulo e Associação Brasileira de Enfermagem. Considerações Finais: este estudo possibilitou analisar a história de vida de uma enfermeira ética e comprometida, que se dedicou à educação e à pesquisa em enfermagem e contribuiu de forma significativa para construção da imagem e desenvolvimento desta profissão na Bahia.

Descritores: Enfermagem; História da Enfermagem; Biografia; História do Século XX; Pesquisa Qualitativa.

\section{RESUMEN}

Objetivos: analizar la trayectoria de vida de Anayde Corrêa de Carvalho y sus contribuciones a la enfermería en Bahia. Métodos: historia oral de vida e investigación documental, con análisis de contenido temático. Resultados: se evidenciaron tres categorías: Trayectoria Personal de Anayde Corrêa de Carvalho; La Escuela de Enfermería de Bahía; y la Escuela de Enfermería de la Universidad de Sao Paulo y la Asociación Brasileña de Enfermería. Consideraciones Finales: este estudio permitió analizar la historia de vida de una enfermera ética y comprometida, que se dedicó a la educación e investigación de enfermería y contribuyó significativamente a la construcción de la imagen y el desarrollo de la profesión en Bahía.

Descriptores: Enfermería; Historia de la Enfermería; Biografía; Historia del Siglo XX; Investigación Cualitativa. 


\section{INTRODUCTION}

The aim of this study was to examine Anayde Corrêa de Carvalho's career in Brazilian nursing and her role as a teacher in managing the Nursing School of the Federal University of Bahia (EEUFBA), from 1949 to 1952 . This choice was based on the contribution this professional made to the growth and strengthening of Brazilian nursing, placing her in a context in which her role in the profession and its struggles and achievements was necessary, from the 1950s to the 1980s, serving as a reference in the search for new guidelines in line with society's aspirations and demands.

In 1949, Anayde Corrêa de Carvalho completed her degree in nursing from the School of Nursing at the University of São Paulo (EEUSP). She was the third dean of EEUFBA in the period in which this School established and consolidated itself ${ }^{(1)}$. She became a professional recognized by her peers, due to her effectiveness as a teacher, a researcher and at the Brazilian Nursing Association (ABEn).

On July 20, 2016, Anayde Corrêa de Carvalho celebrated her centenary with significant work benefitting nursing. Moreover, biographies on her and her career have been used in nursing education, with an emphasis on the History of Nursing, as well as in research of social and political advances in nursing and even in creating theories ${ }^{(2)}$, identifying the community at a specific historical moment ${ }^{(3)}$.

By highlighting Anayde Corrêa de Carvalho's academic career, we explain the relevance of her leadership and contributions to the implementation of EEUFBA and the development of the university hospital, a little-known fact in the history of Bahian and Brazilian nursing. Her contribution and political engagement in the development of Nursing is also evident.

This study is further justified by its contribution to the Memory Center Archive of the Nursing School of the Federal University of Bahia (NUMEE), within the scope of research on the history of the institution.

\section{OBJECTIVES}

To analyze the life and career of Anayde Corrêa de Carvalho and her contributions to nursing in Bahia.

\section{METHODS}

\section{Ethical Aspects}

This research is linked to the Nursing Militancy Policy research project in the State of Bahia, approved by the EEUFBA Research Ethics Committee on May 27, 2014.

In order to select the participant, criteria for use in the interview were specified by means of the Copyright Transfer Agreement. Such instruments set out possibilities and limits for later use $\mathrm{e}^{(4)}$. Moreover, the negotiation between the researcher and the collaborator was established by signing an Informed Consent Term (ICF), in two copies, as recommended by Resolution 466/2012 of the National Health Board (CNS).

The interview was transcribed and transcreated before being sent to the collaborator by mail for checking and validation and, subsequently, the Copyright Transfer Agreement was notarized in order to provide legal support for use. and analysis of the material collected.

\section{Study Type}

This is a descriptive study, in the field of history, specifically in the History of Nursing, using the oral life history method and documentary research. History of Nursing is indispensable for understanding the profession, through understanding contexts and their meanings within the culture of the profession. Therefore, it is necessary to understand the socioeconomic, cultural and political contexts that influenced the history of care giving in order to liberate nursing from the inheritance of the past and to understand the present, seeking constructions for the future based on these analyses ${ }^{(5)}$.

\section{Methodology}

\section{Scenario of the study}

One of the criteria for selecting EEUFBA as the research scenario was its great representation in Bahia and in Brazil. Created by Decree-Law 8.779, of January 22, 1946, it was the first Higher Education Institution in Bahia to introduce modern Nursing. At the time it was known as the School of Nursing and Social Services ${ }^{(6)}$.

In addition, EEUFBA was also marked by the political engagement of its directors. This movement pervades the dimension of the oral history of its leaders, in a period which involved a variety of political, ideological and economic transformations on the world stage. Its directors and professors contributed greatly to the development of Bahian and Brazilian nursing, by allowing the structuring of a curriculum that was innovative for a university in Northeastern Brazil which, since its establishment, has become a reference for other nursing education institutions in Brazil(6).

\section{Collecting and organizing the data}

To reconstruct Anayde Corrêa de Carvalho's life and career, we used interviews and documentary analysis. The interview was conducted in January 2015, at the biographer's residence, in Ribeirão Preto (State of São Paulo). It was decided to use a scripted interview to collect the data, and the final version was analyzed and authorized by the interviewee, with donation to NUMEE in 2016.

The documentary sources were textual and iconographic documents from the collaborator's collection, as well as another interview conducted in 1994, and documents used to reconstruct the history of EEUFBA, belonging to the NUMEE collection (diary of nursing student Maria Julieta Calmon Villas-Boas, reports, newspapers, images), as well as literature on the country and nursing context at the time. The testimonies were identified by the acronym "Dep" followed by the year corresponding to the interview.

The data were organized using Thematic Content Analysis. $A$ priori, thematic axes guiding the analysis were defined, according to the objectives of the study ${ }^{(7)}$. The following categories emerged from these axes: 1- Personal trajectory of Anayde Corrêa de Carvalho; 2 - The School of Nursing at the Federal University of Bahia and 3 - School of Nursing at the University of São Paulo and the Brazilian Nursing Association. 


\section{Data Analysis}

For this qualitative methodological design, data were triangulated through analysis of the collaborator's narrative - oral life history and documentary analysis. Based on the collected material, the data were processed using Thematic Content Analysis, the starting point of which is "the message, whether verbal (oral or written), gesture, silent, figurative, documentary or directly provoked"(7). Thus, the aim of the study centered on the report, and not on the subject or on the reality experienced.

The narratives were categorized according to thematic Context Units, according to three phases or "chronological hubs" which make up the Content Analysis technique: pre-analysis, which consists of skim reading and composing the corpus, choosing the documents, formulating hypotheses, referencing indexes and developing indicators; defining analysis categories; and processing and interpreting results ${ }^{(7)}$.

The categories of analysis were grouped, and their meanings approximated. In addition, a descriptive table was created which allowed biographical outlines to be constructed, in chronological order of events in the interviewee's life history, aligned with the respective thematic axes, establishing a matrix for analyzing the results.

\section{RESULTS}

\section{Personal Life of Anayde Corrêa de Carvalho}

Anayde Corrêa de Carvalho was born in Ribeirão Preto-São Paulo, on her family's farm, on July 20, 1916. Her father, Pedro Corrêa de Carvalho, of Portuguese descent, a coffee and cotton producer, married Elza Morandini de Carvalho, of Germans and Italo-Austrian descent, and they had seven children ${ }^{(1,8)}$.

Anayde and her sisters studied at Colégio Santa Úrsula, run by the French Congregation of Ursulines and responsible for educating the daughters of the coffee elite ${ }^{(1,9)}$. She also studied at the Methodist College, founded by North American missionaries, which operated in a coeducation regime-joint education, aimed at men and women, which broke with the concepts adopted by the schools of the time ${ }^{(9)}$. At this college, she learned English and, in another institution, she studied German.

After completing school Anayde Corrêa de Carvalho taught as a primary teacher at Colégio Santa Úrsula ${ }^{(1,8)}$, a profession which guaranteed women's inclusion in the labor market, in addition to domestic activities and child care.

The choice of a nursing career was influenced by her father and sister Amália Corrêa de Carvalho, a student in the first EEUSP class ${ }^{(1)}$ :

We were encouraged to move forward in life and not stand still. It was so encouraged that we had private English and French classes [...] my father wanted us all to study. [...]. [...]Studying came first. Because my father said that marriage was good for men but for women it was no good [...]. [...] Stay at home, study, work, go to teach. (Dep. 2015)

During her time as a student at EEUSP, the discipline and moral values demonstrated may have influenced the then director, Edith de Magalhães Fraenkel, to later appoint her as a teacher at the institution. Anayde Corrêa de Carvalho finished the nursing course in February 1949, but graduation only took place in October of that year ${ }^{(1)}$, as some colleagues needed to complete their training time to be awarded the degree ${ }^{(10)}$.

For seven months, due to the lack of funds for hiring teachers at EEUSP, Anayde Corrêa de Carvalho was referred to the Head of Nursing at Hospital das Clínicas in São Paulo, Clarice Della Torre Ferrarini, to take over activities at the hospital. She worked in the nursery and, later, as head nurse at the Hospital's 2nd Surgical Clinic ${ }^{(10)}$.

In October 1949, Edith de Magalhães Fraenkel convinced her to go to Salvador, Bahia, together with Jandira Alves Coelho and Wanda Alves Batista, in consideration of a request from the rector of UFBA, Dr. Edgard Santos. EEUFBA was going through a transition period after the departure of dean Haydée Guanais Dourado. The confrontation of ideas and purposes for implementing the nursing curriculum between the dean and the rector led Haydée Guanais Dourado to leave office and, with this, the initial teaching staff of the EEUFBA requested to return to their institutions of origin ${ }^{(11)}$.

Anayde Corrêa de Carvalho remained at the EEUFBA until a former student at the institution was able take over the management, returning to São Paulo in February 1952. In September of the same year she went to the United States of America (USA) on a Kellogg Foundation scholarship to pursue a Bachelor of Science in Nursing Education at Teachers College, Columbia University, New York. She completed this course in June 1954, at which time she returned to EEUSP as a teacher. In her own words, she valued discipline and respect in the training process:

[...] teacher-student, it was more disciplined than today. There was more respect for the teacher, who was a little superior to the students. We more willingly accepted what the teacher said. There was no major discipline problem. One or another student [was] more rebellious [...]. [...] We considered that he knew more. We had to consider it. (Dep. 1994, NUMEE)

\section{The School of Nursing of Bahia}

In a retrospective self-assessment, Anayde Corrêa de Carvalho considered it reckless to send recent graduates to run an entire School, but recognizes the director's show of confidence towards the nurses she had trained. She thought she lacked experience to face the challenge of running a school and, upon receiving the news that she was going to Salvador, this was her reaction:

I said: but Dona Edith, I've just graduated! I don't have much experience [...]. It doesn't matter! You want to. So, go! Dona Edith was an extraordinary person from that point of view. Because she didn't force it, but she had such good will, so much kindness to us, that we ended up doing what she wanted, even if we didn't agree [...] I thought it was because I wasn't prepared to be the dean of a school, as I was recently graduated too. (Dep. 2015)

Despite fear of the unknown, she adopted an attitude of respect for her superior. It appears from the interview that the strict upbringing from the mother, of German descent, contributed to determining her position in society, reverberating in her way of acting and in the construction of her personal and professional identity. 
In addition to the School, she would also work at the Hospital das Clínicas, opened in November 1948. During the process of building the hospital, the School of Nursing was also erected. Edgar Santos longed for a modern hospital, to meet the academic demands of Medicine and Nursing courses at the University.

The rector recognized the "need to create a model school, which would give the Nursing profession an attractive new meaning and impose itself on the community through the technical training and ethical standards of the teachers and studens"(12). For this, it was important to maintain the agreement with EEUSP and promote scholarship links with the Rockfeller and Kellogg foundations, in order to encourage the studies of future teachers at the School of Nursing of Bahia.

On October 20, 1949, Jandira Alves Coelho and Anayde Corrêa de Carvalho arrived in Bahia accompanied by four nurseteachers (Wanda Alves Batista, Maria Virgínia Chagas Gonçalves, Odete Barros de Andrade and Alvina Arruda Cruz - assigned to head the nursing staff at the Hospital das Clínicas) and another teacher, Corina Berlinck, who would take over the Climério de Oliveira Maternity Hospital ${ }^{(6,10)}$. At first they lived at the Hospital das Clínicas, until October 30, 1950, when they were transferred to the newly constructed School building. They were received by the rector Edgard Santos, by the dean of the School of Medicine, José Olímpio, and by dean Haydée Guanais Dourado.

Initially, the departure of Haydée Guanais provoked a feeling of hostility on the part of the students towards the new group from São Paulo who had taken over the EEUFBA:

When we arrived, we were very well received by the rector, of course! He was the one who came to us [...] he looked after us [...] and he received us very well! But, the dirty looks from the others was [...] wow! We had to face up to it! One of them showed me the story of a session that had taken place at the University assembly, which complained about the rector, since he could not do this, saying that Bahia, which had such an important person as what's her face, now needs people from São Paulo to come and head the Nursing School! (Dep. 2015)

Notwithstanding, Anayde Corrêa de Carvalho held firm in the mission delegated by Edith de Magalhães Fraenkel:

[...] I hardly felt that! They said it existed! The students, for example - a dean from São Paulo and why not from Bahia? But I didn't care about that. The dean was the dean, and that's it! [...]. [...]. I thought: we are all Brazilians, full stop! (Dep. 2015)

She noticed greater resistance from the students in the second class, as the first remained at EEUSP for one year to complete internships that did not have teachers and fields of practice at EEUFBA. This need was perceived by Jandira Alves Coelho as soon as she took over the direction ofEEUFBA, sending the students to São Paulo to complement the course ${ }^{(6)}$. The second class stayed only 10 months. According to Anayde, teaching and directing work in Bahia was intense:

But we were practically Jacks of all trades. If we needed to teach, we would teach what was needed! Because as the school was starting, there were not many subjects. Only the primary subjects. We did what was necessary. Because there really were few of us! Then the Hospital das Clínicas of São Paulo sent some teachers. (Dep. 2015)
In another interview, she reaffirms her concern at being a recent graduate, but recognizes that, little by little, she was enjoying and becoming enthusiastic about the task, because in addition to being the vice-dean, and later, the dean, she taught classes, which she found very gratifying. The dean and the vice-dean found the EEUFBA organized, with standards comparable to the EEUSP, this being an aspect that facilitated the progress of the project:

We found Escola da Bahia very well organized. Everything was very well planned. The way the School was being run was easy to follow. The curriculum was very good and it was already considered one of the best schools in the country, at that time. People were already taking [the course] in four years. (Dep. 1994, NUMEE)

The diary of Maria Julieta Calmon Villas-Boas, a student in the first class of the EEUFBA, reiterates the testimony of Anayde Corrêa de Carvalho and demonstrates that the new leadership was gradually becoming part of the student reality:

Today our School is a reality. We had struggles, a lot of work, but what we achieved in harmony and understanding between us, as well as intellectual and scientific development, was wonderful. (Diário Villas-Boas MJ, NUMEE)

The bond formed with the Calmon Villas-Boas family was fundamental in the relationship with the other students and in supporting their management. Coming from a family in which several members were in Brazilian political, economic and literary life, Maria Julieta Calmon and Thereza Calmon understood the difficult time experienced by the school and the importance of their contributions in maintaining the students' enthusiasm and preparing them as leaders, in order to start the work of nursing in Bahia.

In November 1950, the students from the first class returned to Bahia for their graduation, held on December 9 that year. On their graduation day, the new EEUFBA building was inaugurated and the IV National Nursing Congress (CNE) closed, marked by foreign participation, with emphasis on the representatives of the International Council of Nurses $(\mathrm{CIE})^{(13)}$, and by the creation of the Congress Executive Committee ${ }^{(14)}$. Daisy Caroline Bridges, executive member of $\mathrm{CIE}$, attended the congress and participated in discussions with the ABED board on planning the 10th International Congress to be held in Brazil in 1953. In 1951, representatives of the Brazilian Association of Registered Nurses participated in the meeting of the Grand Council, in Brussels, recommending to hold the event in July, due to the climate, this being the first time it would be held in the Southern Hemisphere ${ }^{(14-15)}$.

The experience acquired by Anayde Corrêa de Carvalho at the I National Nursing Congress, in 1947, as a student at EEUSP, facilitated reception of the participants and organization of the event in partnership with ABEn Nacional and ABEn-BA:

The executive Chair was D. Maria Rosa. We had a very big job to take over the School to be able to receive the Congress. Most of the attendees stayed at the School. Preparing the site, doing all that servile work. At this 4th Congress, in addition to domestic chores, I contributed a lot in the cultural part. (Dep. 1994, NUMEE)

Maria Rosa [Souza Pinheiro] was dean [...]. Maria Rosa went there and helped us a lot in organizing the Congress. (Dep. 2015) 
In June 1951, Anayde Corrêa de Carvalho would face a new challenge with the departure of Professor Jandira Alves Coelho, when she assumed direction of EEUFBA for eight months - enough time to set and implement the objectives under her management: "[...] improve teaching conditions; encourage supervisors to study; provide students with intellectual progress; get training camps for the students"(6).

Moreover, the holding of weekly meetings at the Hospital das Clínicas stands out, for conducting clinical studies and debating on topics relevant to both institutions (School and Hospital). Anayde Corrêa de Carvalho valued the qualification of the teaching staff and endeavored to promote the teachers' participation in Congresses, and to train nursing assistants, even thinking about creating a specific course in order to improve the level of auxiliary categories at the hospital ${ }^{(6)}$. Such project, in accordance with Law $775 / 49$, which gave legal support on the minimum requirements for teaching nursing at the $1 \mathrm{st}$ level ${ }^{(14)}$, was prepared and sent to the Rector. At the same time, the head of nursing at the Hospital promoted in-service training for attendants, in order to improve the quality of care provided ${ }^{(6)}$.

During her tenure as dean, the School of Nursing came to have a seat on the University Council, being incorporated into the University of Bahia, as established in article 3 of the first University Statute (Decree 22.637/47). This was a position also argued for by the previous leadership, which sought greater autonomy for the institution.

Anayde Corrêa de Carvalho continued the proposed "living curriculum", implemented by Haydée Guanais Dourado, which aimed to recognize and strengthen nursing in Bahia. For the former dean, the excellence of nursing teaching at EEUFBA was linked to the need to coordinate the curriculum from full time from student to teacher ${ }^{(11)}$ :

D. Edith arrived and called us communicating to us [the students of the 1st class] that we would soon be going [to EEUSP], because the School [EEUFBA] needed us, already trained to prepare services for the other classes. (Diário Villas Boas MJ, NUMEE)

However, she disagreed with the teaching-care integration model proposed by the rector and the former dean of the School. She believed that the two methods would work better when not linked, in different building spaces, in order to be able to dedicate themselves to one or the other entirely, without negatively affecting them:

I didn't like that. I think that integration does not depend on the teacher being a head nurse. It can be with each in their place. [...] If we mix, the teaching staff will always suffer. In my case, it was affected because I ran the Hospital, then when I went to supervise the students, the time had passed. So, the students were affected. But we had to do it too, right at the beginning. It wasn't all bad, because we went round and, in an instant, saw everyone. The Hospital was just starting and had few patients. (Dep. 1994, NUMEE)

With the deadline met, in February 1952, Anayde Corrêa de Carvalho requested to return to São Paulo, passing the leadership of the EEUFBA to Professor Nilza Marques Maurício Garcia, the vice dean.

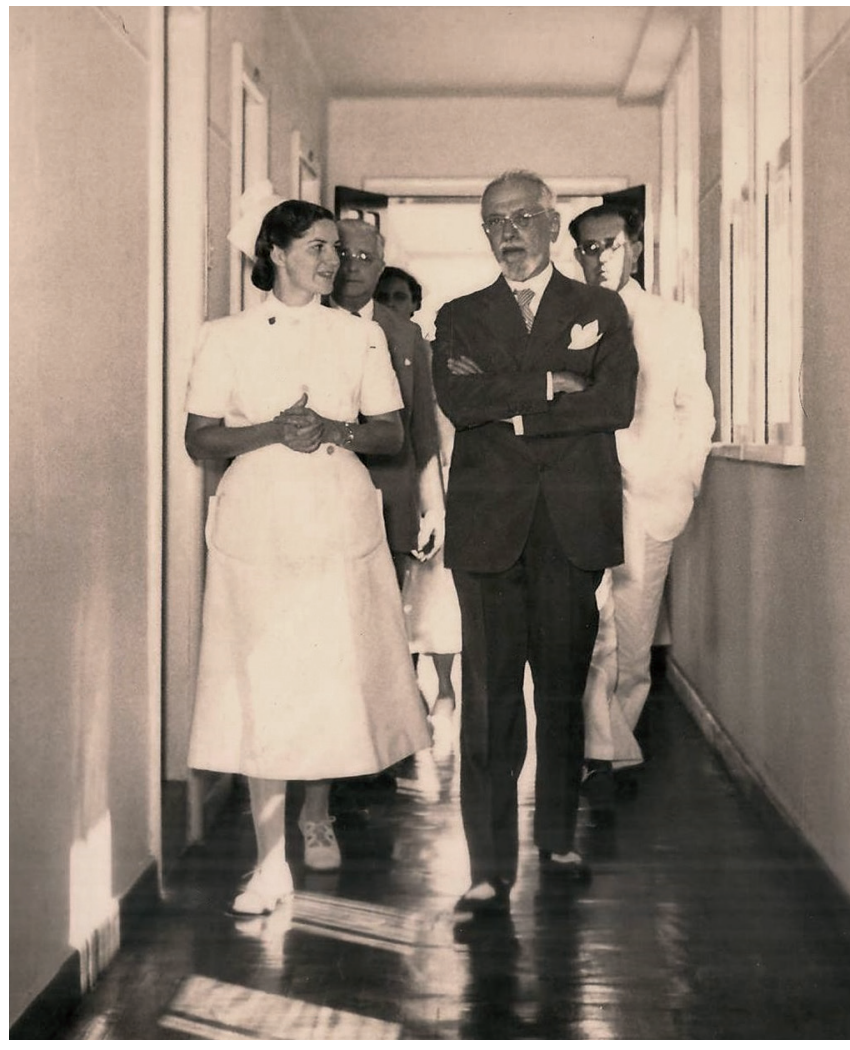

Source: Collection from the Memory Center of the Nursing School of the Federal University of Bahia Figure 1 - Anayde Corrêa de Carvalho at the Nursing School, accompanying then Minister of Education and Health, Ernesto Simões Filho, and Rector Prof. Edgar Santos, Salvador, Bahia, Brazil, 1951

\section{University of São Paulo School of Nursing and Brazilian Nursing Association}

After leaving EEUFBA, Anayde Corrêa de Carvalho returned to EEUSP and took charge of the discipline Fundamentals of Nursing. This coincided with the period of discovery of the mode of transmission and treatment of polio, which opened up possibilities for preparing and registering two vaccines capable of preventing contamination by the virus ${ }^{(10)}$. Once again, she responded to Edith de Magalhães Fraenkel's request to work on the campaign and worked on it until the end of the epidemic.

In September of that year, she went to the United States of America (USA), returning to Brazil in 1954, when she took over the disciplines of Administration Applied to Nursing and Medical Nursing. She also worked on undergraduate and graduate courses, from 1954 to 1962, as coordinator of disciplines related to Administration Applied to Nursing.

In 1969, she was appointed to represent EEUSP in the USP Work on Reform. From 1970 to 1977, she was selected for the students section and advised the Dean Maria Rosa Sousa Pinheiro on curriculum matters.

During her long career at ABEn, she served as a member of several boards and as Coordinator of the Documentation and Studies Commission, the ABEn Statute Reform Commission, Editor of Revista Brasileira de Enfermagem and President of ABEn-São Paulo Chapter.

Regarding the period from 1956 to 1958, when she was elected ABEn-São Paulo Chapter chair, Anayde Corrêa de Carvalho highlights: 
[...] from 56 to 58, I was the Chair of ABEn in São Paulo and tried to defend the profession, union, discussing of bills to try to improve relations between nurses, practitioners and assistants. These meetings were held at USP, with Maria Rosa as coordinator. (Dep. 1994, NUMEE)

From 1959 to 1964, after being elected Coordinator of the ABEn National Statute and Internal Regulation Reform Commission, her main task was to promote the general meeting and make changes to the statute. Then, between 1965 and 1968, she served as editor of the Revista Brasileira de Enfermagem (REBEn):

[...] I worked as Editor of the Revista Brasileira de Enfermagem, with great satisfaction, but it resulted in great frustration. Overworked on the Undergraduate and Graduate Programs, reviewing the articles in the Journal moved into the background, giving rise to more than justified complaints from the associate. (Dep. 1994, NUMEE)

She stood down in 1976, after completing the ABEn documentary, but continued to work, even becoming the first coordinator of the Center for Studies and Research in Nursing (CEPEn), the objectives of which were to encourage the development and dissemination of nursing research and preserve the historical documents of the profession, becoming a great center of political-scientific and historical representation. It was a pioneering work, the idea of Haydée Guanais Dourado and approved, in 1971, at the Assembly of Delegates of the XXIII Brazilian Congress of Nursing ${ }^{(16)}$. In 1986, Anayde Corrêa de Carvalho left ABEn, leaving a great legacy for this entity and for Nursing.

\section{DISCUSSION}

Anayde Corrêa de Carvalho's upbringing and education collaborated for her professional training and performance, since valuing female education was opposed to the feminine ideals determined by the society of the time.

In the early 20th century, the situation in the municipality of Ribeirão Preto was shaped by coffee supremacy. Thus, public and private educational establishments were created in the region, as well as religious entities, associations and congregations, which significantly marked the education of women ${ }^{(9)}$. Many women, whose secondary studies took place in Catholic schools, did not follow the standard of wife and mother common at the time, but sought the path of professionalization as teachers, given the lack, within the scope of teaching, of specific professional qualification ${ }^{(17)}$.

The teaching of foreign languages was part of the curriculum of these schools for women from Ribeirão Preto belonging to the oligarchies of the time. Such institutions were marked by teaching quality, had discipline as a fundamental point and allowed innovations in the female education curriculum ${ }^{(9)}$.

Anayde Corrêa de Carvalho's level of education facilitated her access to the profession at EEUSP, since this school received financial incentives from the State when commissioning primary teachers to study Nursing. It sought to admit students with a higher education level, in order to maintain a high standard of quality and teaching ${ }^{(18-19)}$.

This strategy was also adopted at EEUFBA, when Haydée Guanais Dourado asked the then Secretary of Education and Health of the State, Dr. Anísio Teixeira, to commission primary teachers to make up the second class of the EEUFBA. At this meeting, she discovered the educator's admiration for the college where she studied, he volunteered to teach classes for nursing teachers and authorized the selection of teachers for the nursing course. The success experienced by Haydée Guanais Dourado at EEUSP motivated her to reproduce this model in Bahia ${ }^{(11,20)}$.

When Anayde Corrêa de Carvalho arrived in Bahia, in 1949, there were only 23 nursing schools in Brazil, of which ten were concentrated in the states of Rio de Janeiro and São Paulo and in Bahia there was only EEUFBA ${ }^{(21)}$. This was a very small number in relation to the country's demand, which increased the institution's responsibility for internalizing nursing in Brazil during this period.

In the first group of teachers at EEUFBA, six were from the second class of EEUSP graduates (1947): Maria Cleide Teixeira Barroso (the only one who remained in Bahia), Maria Perales Aires, Isabel Maria de Mesquita, Jacy de Souza Moraes, Olga Verderese and Celina Jaeger Birnfeld. These teachers made up"the first group of scholarship holders from SESP, from various states in Brazil, who would have to replicate the learning in their places of origin"(18).

There was great concern with constructing the image of nursing in Bahia. EEUFBA was the first Public School of Nursing in the North-Northeast of Brazil and the training of its first class already showed to medical professionals and the population the quality required in the emerging profession ${ }^{(11)}$. The first eight students from EEUFBA were interviewed and evaluated for personality traits, level of cultural and intellectual knowledge, and they mostly belonged to families with economic and social representation in the State. The first class was" "handpicked"(20), as it would be an example of the ideal of nursing for the following classes.

Anayde Corrêa de Carvalho's perception of the selection criteria was different. For her, "status", contacts with influential people in Bahian society and family prestige were not important, as she wanted students who had a real interest in studying nursing. Likewise, she assessed responsibility for patient care, whether the candidate was able to improve technically and scientifically and whether or not she had the "profile" for the profession.

The main purpose was to maintain the quality of the course, maintaining the innovative curriculum project implemented by Haydée Guanais Dourado and the steps taken by Jandira Alves Coelho, shaping them according to her personality.

A list of the activities at EEUFBA in 1952 reaffirms Anayde Corrêa de Carvalho's professional commitment in the period in which she was at the head of the School, recording the impossibility of developing fields of practice in Salvador due to the lack of a Public Health Nursing Service at the State Health Department. There was an attempt to prepare the field with patients from the outpatient clinic of Hospital das Clínicas, but it was realized that this would not be possible, as they could not develop the practice of Maternal and Child Hygiene and regular health exams because they did not fit in with the hospital.

During this period, the professional relationship with the newly qualified teachers was strengthened. Professor Nilza Garcia became the vice-dean of the school together with Anayde Corrêa de Carvalho until her return to São Paulo, going on to become the fourth dean of the EEUFBA. According to Anayde Corrêa de Carvalho, the students of the first class proved to be great allies for continuity in the purpose of increasing visibility and appreciation of the Nursing School of Bahia. 
She returned to São Paulo only one year and two months after the first class graduated, showing her commitment to what was agreed between the School of Nursing of Bahia and the School of Nursing of USP. The agreement with EEUSP came to an end.

With regard to $A B E n$, for five years Anayde Corrêa de Carvalho dedicated herself to constructing the documentary celebrating the institution's 50th anniversary ${ }^{(1)}$. She paid for the trips to collect data and conduct interviews herself, recognizing ABEn's poor cash flow to finance the research and dedicated herself to this project, to the point of giving up the selection process for a doctorate offered to EEUSP professors in 1971.

The book"Brazilian Nursing Association (ABEn), Documentary 1926-1976", is considered by various researchers to be a legacy for the History of Brazilian Nursing. It is the most complete and reliable work on $\mathrm{ABEn}$, both for the volume of information and for the thorough record of half a century of the association. Due to its importance and, after the first edition of 1976, it received a second updated edition in 2008 , however, the content remained the same ${ }^{(8,14)}$. The book is considered a heritage, a legacy to be passed on to the next generations of nurses who fight for Nursing and for the memory of ABEn and the profession ${ }^{(14)}$.

In this sense, Anayde Corrêa de Carvalho emphasized the importance of scientific advance and the art of Nursing, but made a point of pointing out that the profession must always be guided by humanization. For her, the patient needs to be the center of care and not just an object of study ${ }^{(8)}$.

She views herself as a simple woman, who is not flattered by the important work or positions occupied during her career:

[...] nursing is to serve others. [...] it is not wanting status. It is to love others. (Dep. 1994, NUMEE)

Despite her great contribution to Brazilian nursing, Anayde Corrêa de Carvalho was more of a backstage person than spotlight. This has caused her name to pass unremarked in the History of Brazilian Nursing ${ }^{(8)}$.

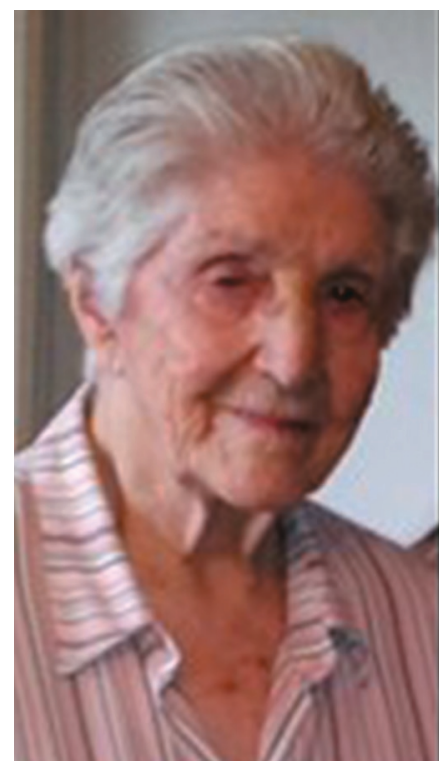

Source: Researcher's collection. Reproduction authorized by Anayde Corrêa de Carvalho. Figure 2 - Anayde Corrêa de Carvalho, Ribeirão Preto, São Paulo, Brazil, 2015

\section{Study Limitations}

Limitations are the few studies carried out within the scope of the EEUFBA and the existence of previous studies on the biography. In this sense, we sought to fill gaps and take views not previously discussed. In addition, the methodology used required more time between the execution of the interview and the returns made with the interviewee, which increased the time until possible publication.

\section{Contributions to the area of Nursing, Health or Public Policy}

The results of this study enable us to reflect on the trajectory of women who were born in the first decade of the 20th century and broke the paradigms attributed to the women of their time. Anayde Corrêa de Carvalho's professional career, as dean of the Nursing School of Bahia, highlighted important challenges: beginning and consolidating the social visibility of nurses in Bahia; implementing and consolidating an innovative curriculum in the University environment; and, in the Northeast region of Brazil, achieving leadership spaces at the University and at the University Hospital. Thus, the study made it possible to understand the importance of preserving the memory of Nurses and teachers who were leaders in the profession and contributed both to the enhancement of the nurse's image in Bahia and Brazil and to the recognition of the training provided by the UFBA School of Nursing.

In addition, by taking a more in-depth look at a life and career, the research has made it possible to expand knowledge about the challenges experienced and the legacy left by these professionals to keep this story alive.

\section{FINAL CONSIDERATIONS}

Anayde Corrêa de Carvalho's personal life and career shows the importance of a nurse who contributed to the recognition and development of Nursing. Always dedicated to her studies, she was a serious nurse, committed and with an ethical posture - attributes that made her a reference for the profession.

As dean of the EEUFBA, she achieved the objectives outlined in her management and designated by Edith de Magalhães Fraenkel when she was sent to Bahia: maintaining teaching quality, continuing the purpose of giving greater visibility and appreciation to the Nursing School of Bahia and preparing the training camps for the students.

The relevance of her work at EEUSP and the positions she assumed at ABEn, especially preparing the ABEn Documentary (1926-1976), enabled her to make important contributions that mark the History of Brazilian Nursing.

The present study made it possible to identify the lucidity and determination of this nurse, as well as her immense effort in the struggle for a political-social space that underlies the present and enables the future of Brazilian nursing. Anayde Corrêa de Carvalho left her earthly mission in February 2019, at the age of 102 , but her legacy continues to evolve.

\section{ACKNOWLEDGEMENT}

Thanks to Professor Dra. Taka Oguisso, for enabling us and arranging the meeting with Anayde Corrêa de Carvalho, at the biographee's residence, in Ribeirão Preto. We are grateful for the trust placed in us, the bibliographies indicated and the opportunity for this dive into the history of nursing. 


\section{REFERENCES}

1. Oguisso T. Trajetória profissional de Amália e Anayde Corrêa de Carvalho. In: Oguisso T, Freitas GF, González JS. Enfermagem: história, cultura dos cuidados e métodos. Rio de Janeiro: Águia Dourada;2016. 316 p.

2. Padilha MI, Nelson S, Borenstein MS. As biografias como um dos caminhos na construção da identidade do profissional da enfermagem. Hist Cienc Saúde-Manguinhos. 2011;18(Suppl 1):241-252. doi: 10.1590/S0104-59702011000500013

3. Bloch ML. Apologia da história ou o ofício de historiador. Rio de Janeiro: Zahar; 2001. 159 p.

4. Meihy JC, Holanda F. História oral: como fazer, como pensar. 2a ed. 3a reimpressão. São Paulo: Contexto; 2014. 175 p.

5. Padilha MICS, Borenstein MS. História da Enfermagem: ensino, pesquisa e interdisciplinaridade. Esc Anna Nery. 2006; 10(3):532-8. doi: $10.1590 / \mathrm{S} 1414-81452006000300024$

6. Fernandes JD (coord.). Memorial Escola de Enfermagem: 1946-1996. Salvador: Universidade Federal da Bahia; 2001. 410 p.

7. Franco ML. Análise de conteúdo. $4^{a}$ ed. Brasília: Liber Livro;2012.

8. Oguisso T, Campos PF, Santiago ES, Luchesi LB. Anayde Corrêa de Carvalho: legado histórico para a enfermagem brasileira. Cult Cuidados. 2013;17(37):30-41. doi: 10.7184/cuid.2013.37.04

9. Furtado AC. História de uma instituição escolar católica: o colégio Nossa Senhora Auxiliadora de Ribeirão Preto no cenário do interior paulista (1918-1944). Cad Hist Educ [Internet]. 2015[cited 2020 Mar 13];14(2):483-503. Available from: http://www.seer.ufu.br/index.php/ che/article/view/32550/17823

10. Carvalho AC. Escola de Enfermagem da Universidade de São Paulo: resumo histórico, 1942-1980. Rev Esc Enferm USP. 1980;14(Suppl1):1-271. doi: 10.1590/0080-62341980014esp00001

11. Oliveira NL, Ribeiro JC, Costa HOG, Melo CMM, Silva GTR. 100 anos de Haydée Guanais Dourado: contributos para a enfermagem brasileira. Rev Baiana Enferm. 2016;30(2):1-12. doi: 10.18471/rbe.30i2.15041

12. Santos RF. Vidas paralelas. $2^{\text {a }}$ ed. Salvador: EDUFBA; 2008. 148 p.

13. Mancia JR, Padilha MICS, Ramos FRS, Cordova FP, Amaral NV. Congresso Brasileiro de Enfermagem: sessenta anos de história. Rev Bras Enferm. 2009;62(3):471-9. doi: 10.1590/S0034-71672009000300023

14. Carvalho AC. Associação Brasileira de Enfermagem 1926-1976: documentário. 2a ed. Brasília: ABEn; 2008. 574 p.

15. Bridges DC. A history of the International Council of Nurses 1899-1964: the first sixty-five years. England: Pitman Medical Publishing; 1967.

16. Leite JL, Paim L. A trajetória do Centro de Estudos e Pesquisas em Enfermagem: Jornal da Associação Brasileira de Enfermagem [Internet]. 2006 [cited 2016 May 3];48(2):18-20. Available from: http://www.abennacional.org.br/home/download/atrajetoriadocentro_de_estudos_e_ pesquisas_em_enfermagem.pdf

17. Martins PC. Práticas e representações femininas do Catolicismo à cultura letrada: o modelo civilizatório europeu sobre o Brasil, no início do século XX. Rev Bras Hist Relig ANPUH. 2010;3(8):183-210. doi: 10.4025/rbhranpuh.v3i8.30354

18. Campos PF. Memorial de Maria de Lourdes Almeida: história e enfermagem no Brasil pós-1930. Hist Cienc Saude-Manguinhos. 2013;20(2):609-25. doi: 10.1590/s0104-59702013000200014

19. Campos PF, Oguisso T. A Escola de Enfermagem da Universidade de São Paulo e a reconfiguração da identidade profissional da enfermagem Brasileira. Rev Bras Enferm. 2008;61(6):892-8. doi: 10.1590/S0034-71672008000600017

20. Barreira IA, Baptista SS. Haydée Guanais Dourado: carisma e personalidade a serviço de um ideal. Rev Bras Enferm. 2002;55(3):275-92. doi: 10.1590/S0034-71672002000300007

21. Ministério da Saúde (BR). Enfermagem (leis, decretos e portarias). 2a edição revista e aumentada. Serviço Especial de Saúde Pública. Rio de Janeiro: 1959. 